quinquennium; and disordered action of the heart only 0.29 in comparison with 0.56 .

Amongst the troops serving at home those quartered in the Tondon Bistrict always show more sickness than any others. The ratios for the whole of the troops at home have been stated above. In the London area the admissions were 677 , the number constantly sick $40 \cdot 3$, and the invaliding 17.5 per 1000 ; in the Western Command, on the other hand, these ratios were only $277,12.9$, and 10.5 respectively. Comparing the different arms of the service, the Household Cavaleg have the highest admission-rate (654) and the Foot Guards the highest number constantly sick $(38 \cdot 6)$. The respective figures for Infantry of the Line are 407 admissions and 23.8 constantly sick per 1000. The Ifoot Geards, however, show a great improvement compared with the corresponding ratios for the past five years, which were 731 admissions and $52 \cdot 6$ constantly sick per 1000; while the Household Cavalry are rather worse this year than their quinquennial average ( 650 admissions and 25.2 constantly sick per 1000). From a table that is farnished in the report, comparing the death-rates of soldiers with the rates for civilian males, aged 15 to 35 , from certain diseases, the advantage appears to be generally on the side of the military. Thus, the enteric fever death-rate was 72 per 1,000,000 compared with 143 for civilians; for tubercle of lung, 273 compared with 1438, and for other tuberculous diseases 40, compared with 211 . Alcoholism caused only 24 deafts per $1,000,000$ in soldiers, compared with 31 in civilians. Allowance must be male for invaliding, which would discount the apparent advantage in taberculous diseases, but would not affect enteric fever or alcoholism Ehese diseases are therefore less fatal in the soldier than in the ciriliars of similar age.

The most fatal diseases were pneumonia $(0.41$ death per 1000), tabercle of the lung $(0.27)$, and valvular heart disease (0.18). The diseases causing most sickness were gonorrhœa, Gyphilis, and soft chancre, which together caused a constantky sick rate of 6.20 out of the total 21.72 per 1000 ; this, however, is an improvement on the average for 1906-08, wich was 7.90. The chief diseases causing invaleding were tubercle $(1.74$ per 1000), diseases of the nercous system $(1 \cdot 70)$, and heart disease $(1 \cdot 41)$; of these the Guberculous group show a slight increase on the quinquenaial average $(1 \cdot 69)$. In last year's report attention was draw to the need of some coöperation between the military authorities and municipal bodies or charitable institutions possessing open-air sanatoriums, which would offer to men on their discharge from the army some prospect of that after-are and attention which is so necessary if they are to recover their places in civil life as able-bodied citizens. Infortuately, it has not been found possible, up to the present, to devise any general scheme to this end; but for the Aldershot Command four beds are reserved in the Frimley Banatorium for discharged soldiers, whose condition gives hape for cure or improvement, on payment of $10 \mathrm{~s}$. a week, lalf of which is contributed by the Soldiers and Sators ${ }^{7}$ elp Society, and half by the regiment. We think, lowever, that the whole cost of this sanatorium treatrestin, after discharge from the army, should not fall on the rivate (or voluntary) charitable resources of the military, whether through regimental agency or the Help Society. Most of the men invalided would become chargeable to the gublic sooner or later after their discharge; and it seems only fair that the public generally - that is, the civil authorities-should bear some of the burden in the way previoesily suggested, namely, by allotting accommodation to ex-soldiers in sanatoriums, preferably in the territorial area to which they belong. Diseases of the heart and circulatory gystem caused nearly as many deaths $(0.32$ per 1000) as the quinquernial average $(0.36)$; but led to much less invaliding, I.61 per 1000 compared with 3.09. This indicates the suc cess of the measures now being taken to eliminate heartatrain, as far as possible, from the exercises of the soldier and especially that the physical training, as now carried on, is in agreement with sound physiological teaching.

Tenereal diseases caused 28.6 per cent. of the total amount of aickness; in the decennium, 1891-1900, they caused 31 per cent. The improvement appears to be very slight, but it must be remembered that the total sick ratio in that period was 39.52, while in 1909 it was $21 \cdot 12$ per 1000 ; there is, therefore, really a very considerable reduction in the amount of these diseases. In 1901 there were 847 men constantly sick in hospital with venereal disease, out of a force of 100,811 ; in 1909 there were 685 men similarly hors de oombat out of a force of 110,492 . There is no doubt that the spread of temperance among soldiers is the chief, though not the only, reason for this improvement. Great variation is seen, as always, in the incidence of these affections. In the London District they caused 160 admissions per 1000, at Aldershot 48, on manœuvres 22 . The bad pre eminence of the London District (that is, the Household Troops) is less marked than in recent years, for in 1907 there were as many as 208 admissions per 1000 for venereal disease, but it is unsatisfactory. None of the specific infectious diseases were prevalent in 1909 except influenza, which caused 18.4 admissions per 1000 , but it was not of a severe type.

\section{PLAGUE IN RUSSIA AND IN THE NEAR AND FAR EAST.}

(From the British Delegate to the Constantinople BOARD OF HEALTH.)

\section{Plague in Odessa.}

THE following has been the course of the plague outbreak in Odessa since the date of my last letter on this subject (published in THE LANCET of Jan. 7th, p. 59). In the week ending Nov. 5th 4 cases with 1 death occurred in the town, none in the district round. The totals had then reached 140 cases and 43 deaths. Apparently no further cases occurred in November or December, but on Jan. 11th (Dec. 29th, Old Style) 2 fresh cases were reported. Since then Odessa and neighbourhood seem to have been free from plague. It is noted that some time in November, out of 522 rats caught in the town and examined bacteriologically one was found to be plague-infected.

\section{Plague in the Kirghiz Steppes.}

A large number of plague centres seem to have formed in the past few months in various parts of the Kirghiz steppes of the Astrakhan government. On the island of Kaklen, in the second arrondissement of the first okrug (circuit) of these steppes 6 cases of plague, all fatal, occurred between Oct. 13th and 30th (0ld Style). There were no further cases here in the following week. In the Djalpak settlement (urotohishtohé), situated in the fourth arrondissement of the second okrug, 15 cases of the disease with 11 deaths were recorded between Nov. 1st and 12th. In the Djalpak-Tchagyl settlement (probably the same as the one just named) 20 cases with 19 deaths had occurred by Nov. 15th. One further case was reported here on the $22 \mathrm{nd}$. In the Naurzali-Tchagyl settlement, situated in the second arrondissement of the first otrug, 4 deaths from pneumonic plague were reported on Nov. 18th. Other reports put the figures for this place at 5 cases and 5 deaths between Nov. 10th and 17th, followed by 1 case on the 21st, which died on the 25th. In the Mueren settlement 1 fatal case occurred on Nov. 4th, and in that of Abil-Ishken ( $t$ welfth arrondissement of first okrug) single cases (all fatal) were seen on Nov, 9th, 11th, 14th, and 16th. In the Tchushak settlement (second okrug, third arrondissement), 1 person fell ill on the 23rd and died on Nov. 24th In the Biskyz settlement (on the frontier of the second okrug) 10 cases of plague with 9 deaths occurred between Nov. 17 th and $30 \mathrm{th}$, and 2 further cases were recorded here, at a date not stated. Some time in November the disease appeared in the Boman settlement (second olrug, second arrondissement); at that of Kara-Syr (fifteenth arrondissement of first olirug), where 7 cases and 6 deaths occurred; and in that of Musrep-Tchagyl, in the sixth arrondissement of the Sarak district, where 5 cases of pneumonic plague, all fatal, were recorded. In the Kolden settlement, in the second arrondissement of the Narynsk district, 4 suspected cases with 1 death occurred on or about Dec. 12th; 1 suspected and fatal case was seen in the Kolybai settlement (sixth arrondissement of the Kamysh-Samara district) at a date not named; and 5 cases with 1 death occurred there between Dec. 10th and $13 \mathrm{th}$, followed by another case on the 16th. In the Iliman settlement (third arrondissement of the second okm 1 fatal case occurred on Dec. 19th. In the Kosai settlement (second arrondissement of the second okrug) 5 cases and 2 deaths had occurred in the first half of December, followed 
by 13 casts and 6 deaths between Dec. 17th and 25th; 2 further deaths occurred here on the 26th.

In the settlement of $\mathrm{Ak}$-Tchagyl, in the district of KamyshSamara, 9 cases of plague with 2 deaths were recorded between Dec. 22nd and 27th; 2 further deaths occurred here on the $28 \mathrm{th}$, and 4 more between that date and Jan. 3rd. At a place called Sheshekti, in the second okrug of the Primorsk (or Maritime) district, 2 fatal cases occurred on Dec. 16th. Finally, at Bezo.Kyzo, in the first okrug of the Primorsk district, 1 death from plague occurred on Dec. 22nd, and 2 cases with 1 death on the $30 \mathrm{th}$; these last occurred in members of a family under cordon.

From the above rapid summary it will be seen that plague has been present in at least 17 different places in the Kirghiz steppes of the Astrakhan government, and that these places are situated in many different parts of those regions. All the dates mentioned in this paragraph are according to the Old Style.

\section{Plague in Transbaikalia and Manohuria.}

From telegrams published in the English papers it would seem that not only has a severe epidemic of plague established itself in Transbaikalia and in Manchuria, but that the disease in its worst form-the pneumonic-has spread thence to some of the most densely inhabited portions of China, where it has already caused a high mortality. No official news has been received here respecting the epidemic in China, but the following information has become available, from Russian official sources, concerning the outbreaks in Transbaikalia and Manchuria.

In the Chinese population in the settlement round the station of Manchuria, on the China-Oriental Railway, from the beginning of October down to Nov. 3rd (Old Style), 212 cases of pneumonic plague, 207 of which were fatal, occurred. At the Tchalainor mines 31 cases, all fatal, were recorded among Chinese labourers between Oct. 20th and Nov. 1st. Single cases had then occurred at the stations of Tchalantun, Bukheidé, Khailar, and Harbin. At the Tarbagatai mines, in Transbaikalia, 2 deaths had occurred ; at Verkhneudinsk, 1 death; at Petrovsk, 4 cases and 1 death (these included the cases of Dr. Noniava and 2 sanitary employees). At this time an order was issued forbidding Chinese labourers to enter the Primorskaia (or Maritime) Province from Manchuria until the end of the epidemic, and other measures were taken. In Transbaikalia the outbreak as a whole does not seem to have been a very severe one. From Sept. 15th to Nov. 9th the totals for the province were put at 28 cases with 25 deaths. In November an increasing number of corpses of Chinese found dead in the streets was reported from Harbin; and towards the end of the month the disease was said to be causing an increasing mortality at Fu-Chia-tien, and in towns and villages situated on the trade roads between Tsitsikar and Blagoviésctchensk. In mid-December some 30 cases were daily occurring in the streets and houses of Fu-Chia-tien.

Meanwhile the disease had been causing a high mortality in the region of exploitation of the Manchuria-Oriental Railway. Between Oct. 13th and Nov. 21st 468 cases with 466 deaths had been registered here among Chinese, and 11 cases with 10 deaths among Russians. (The enormously high rate of mortality will be noticed.) Apparently the epidemic died down about this time, as the totals down to Dec. 10th were placed at only 491 cases and 488 deaths among the Chinese, and (as before) 11 cases and 10 deaths among Russians. But by some date not clearly stated, towards the end of December, these same totals were reckoned at 588 cases with 578 deaths for the Chinese and 14 cases with 13 deaths for the Russian population. At the moment of writing a still later official bulletin has come to hand, and this states that in the region above defined 154 cases of plague with 152 deaths occurred between Jan. 1st and 6th; that of these 136 cases with 135 deaths were recorded in the town of Harbin, and the rest in six other stations on the railway, and that the total numbers since Oct. 13th down to Jan. 6th had been 831 cases with 821 deaths among the Chinese, and 25 cases with 24 deaths among Europeans. Professor Zabolotny, the well-known Russian anthority on plague, and Dr. Predtéchenski have been sent to the infected districts in Manchnria, with powers to organise measures for the control of what is evidently a serious epidemic of plague, apparently in its most fatal form. In this paragrap, also, all the dates mentioned are according to the Old Style.

$$
\text { Plague in Batoum and Bakw. }
$$

A single suspected case was reported from Batonm on Jan. 24th. On Dec. 2nd (15th) a case also occurred in Bakn : the patient, a young girl, died, and there was bacteriologican proof that the disease was plague.

\section{Plague in Jeddah.}

The seasonal revival of plague in Jeddah has again to be reported. The first case was seen on Dec. 22nd ; it was only seen after death. The patient, a native porter, bad died after a six days' illness. No other case was reported antil Jan. 15th, and a few further cases have occurred since, including those of two Indian pilgrims isolated on $\mathrm{Jam}_{2} 2 \mathrm{2nd}$. Constantinople, Jan. 28th.

\section{MEDICINE AND THE LAW.}

\section{Medical Ireatment after School Inspection: the Iegal Position} of Parents.

A CORRESPONDENT calls attention to a prosecution seccessfully instituted at Bridgwater in December of last year agasns the father of a little girl attending a local elementary scbool in the neighbourhood. The school medical officer had fomd the child's sight to be very defective, and he deposed in the witness box that neglect of treatment would prove detrimental to her physical ability in several ways. In consequence of the report made by the school medieal offeer the defendant, described as a "groom-gardener," received notice requesting him to send his child to Bridgwater to be examined by the county oculist, the provision of spectacles being apparently the limit of the treatmente contemplated. The parents, however, took no steps in the matter, and the father, who pleaded guilty before the magistrates, expressed himself as being personally quite "indifferent." He treated it as the business of his wife to which she should attend, and stated that he could not make her take the child to the oculist. The bench intlicted a fine of $£ 2$ with costs, of which none will disapprove, wat the correspondent referred to suggests that the success of the prosecution may have been due to the openly expressed indifference of the father to his child's welfare, and to the neglect of both parents to take any steps whatever to remedy a source of suffering to their child, to which their notice had been called and for which a remedy was offered to them. He asks for the expression of an opinion as to what would happen in a parallel case where the parents refused to allow a child to submit to a surgical operation. Our correspondent, no doubt, has in his mind not infrequent case of the injured workman who claims compensation for an accidental injury, the effects of mish might be removed or mitigated by a surgical operation which he declines to undergo. To quote from his letter; he writes "It would be of great interest to those, like myself, concerned in school management, to know whetber, bad the condition of the child necessitated operation for its adesuate treatment, for instance, had it been deaf owing to adenoid vegetations, it is likely that the parent could bave been successfully prosecuted under the same section $^{3}$ for failing to take steps to have such operation carried ont. My own opinion is that unfortunately such a prosectation would have failed, and that in the case reported it was the admitted indifference of the parent that enabled the prosecution to be successful."

We do not recall any quite similar case brought before the High Court on appeal in which the law relating to the subject has been discussed, and definite principles laid down for the guidance of courts of petty sessions and other tribunals, bnt possibly other readers may have had experience of prosecutions instituted successfully or unsuccessinlly withont ang further question being raised. In our view all such prosecutions must depend upon the facts of the indiridual ease brought forward and upon the evidence adduced as to the necessity for the operation for the relief of suffering in the child, the certainty of its fulfilling its object, the absence on danger to the patient, the extent to which inconveniense as

1 Children Act, 1908, Section 12. 